\title{
PLURALISME AGAMA DI INDONESIA
}

\author{
Oleh : \\ Umi Hanik *
}

\begin{abstract}
ABSTRAK
Pluralisme agama sendiri dimaknai secara berbeda-beda di kalangan cendekiawan Muslim Indonesia, baik secara sosiologis, teologis maupun etis. Secara sosiologis, pluralisme agama adalah suatu kenyataan bahwa kita adalah berbeda-beda, beragam dan plural dalam hal beragama. Pengakuan terhadap adanya pluralisme agama secara sosiologis ini merupakan pluralisme yang paling sederhana, karena pengakuan ini tidak berarti mengizinkan pengakuan terhadap kebenaran teologi atau bahkan etika dari agama lain. Pertama, adanya keterbukaan atau transparansi. Kedua adalah menyadari adanya perbedaan. Perbedaan adalah sesuatu yang wajar dan memang merupakan suatu realitas yang tidak dapat dihindari. Ketiga adalah sikap kritis, yakni kritis terhadap sikap eksklusif dan segala kecenderungan untuk meremehkan dan mendiskreditkan orang lain. Keempat adalah adanya persamaan. Suatu dialog tidak dapat berlangsung dengan sukses apabila satu pihak menjadi "tuan rumah" sedangkan lainnya menjadi "tamu yang diundang". Dan yang terakhir (kelima) adalah ada kemauan untuk memahami kepercayaan, ritus, dan simbol agama dalam rangka untuk memahami orang lain secara benar. Masing-masing pihak harus mau berusaha melakukan itu agar pemahaman terhadap orang lain tidak hanya di permukaan saja tetapi bisa sampai pada bagiannya yang paling dalam (batin).
\end{abstract}

Kata Kunci : Pluralisme, Agama, Kerukunan, Indonesia.

\section{Berbagai Perspektif Pluralisme Agama}

Berbicara tentang hubungan antar agama, wacana pluralisme agama menjadi perbincangan utama. Pluralisme agama sendiri dimaknai secara berbeda-beda di kalangan cendekiawan Muslim Indonesia, baik secara sosiologis, teologis maupun etis. Secara sosiologis, pluralisme agama adalah suatu kenyataan bahwa kita adalah berbeda-beda, beragam dan plural dalam hal beragama. Ini adalah kenyataan sosial, sesuatu yang niscaya dan tidak

\footnotetext{
* STAIN Kediri.
} 
dapat dipungkiri lagi. Dalam kenyataan sosial, kita telah memeluk agama yang berbeda-beda. Pengakuan terhadap adanya pluralisme agama secara sosiologis ini merupakan pluralisme yang paling sederhana, karena pengakuan ini tidak berarti mengizinkan pengakuan terhadap kebenaran teologi atau bahkan etika dari agama lain.

Sebagaimana yang dikemukakan oleh M. Rasjidi bahwa agama adalah masalah yang tidak dapat ditawar-tawar, apalagi berganti. ${ }^{1}$ Ia mengibaratkan agama bukan sebagai (seperti) rumah atau pakaian yang kalau perlu dapat diganti. Jika seseorang memeluk keyakinan, maka keyakinan itu tidak dapat pisah darinya. ${ }^{2}$ Berdasarkan keyakinan inilah, menurut Rasjidi, umat beragama sulit berbicara objektif dalam soal keagamaan, karena manusia dalam keadaan involved (terlibat). Sebagai seorang muslim misalnya, ia menyadari sepenuhnya bahwa ia involved (terlibat) dengan Islam. ${ }^{3}$ Namun, Rasjidi mengakui bahwa dalam kenyataan sejarah masyarakat adalah multicomplex yang mengandung religious pluralism, bermacam-macam agama. Hal ini adalah realitas, karena itu mau tidak mau kita harus menyesuaikan diri, dengan mengakui adanya religious pluralism dalam masyarakat Indonesia. ${ }^{4}$

Dapat dicermati bahwa Rasjidi tidak memandang adanya pertemuan dalam masalah-masalah teologis. Pandangan pluralismenya tidak berarti adanya pertemuan dalam hal keimanan, namun hanya merupakan pengakuan atas keberadaan agama-agama lain. Pandangan pluralismenya tidak sampai masuk pada perbincangan tentang kebenaran-kebenaran yang ada di dalam agama lain. Ia sama sekali tidak menyinggung tentang hal itu. Namun demikian, ia juga tidak memandang kesalahan-kesalahan ajaran teologis dari agama lain. Kritiknya terhadap agama lain adalah kritik sosial, dalam arti bahwa ia mengritik praktek-praktek misi atau zending dari agama Kristen. Ia

1 Argumen ini dikemukakan oleh Prof. Rasjidi dalam satu tulisannya yang disampaikan dalam Pidato Sambutan Musyawarah Antar Agama, 30 November 1967 di Jakarta. Penulis mendapati tulisan ini dari dua sumber, yakni di dalam Majalah Al-Djami'ah, Nomor Khusus, Mei 1968- Tahun ke VIII dan buku karangan Umar Hasyim Toleransi dan Kemerdekaan Beragama dalam Islam sebagai Dasar Menuju Dialog dan Kerukunan Antar Agama. Dalam konteks ini, penulis memfokuskan diri dari sumber yang pertama.

2M. Rasjidi, Al-Djami'ah, Nomor Khusus, Mei 1968 Tahun ke VIII, hlm.35.

${ }^{3}$ Ibid.

${ }^{4}$ Ibid. 
mengritik aktivitas misi atau zending tersebut. Ia tidak mengritik berbagai ajaran teologis yang ada di dalam agama Kristen.

Karena itulah pola yang dipakai Rasjidi adalah pola responsif atas persoalan yang berkembang, misalnya tentang kristenisasi, sehingga terkesan defensif. Apa yang dikemukakannya adalah sebuah pembelaan, sebuah dialog bertahan, bukan menyerang. Pembelaan Rasjidi atas berbagai persoalan yang menimpa umat Islam disampaikan secara terus-terang dan terbuka, bahkan kadang kalah tidak dapat menghindari munculnya tuduhan, tudingan dalam dalam hal-hal yang empirik (aktual). Ia tidak pernah menutupi sesuatu pun, meskipun hal itu terasa pahit dan keras, misalnya tentang apa yang dilakukan oleh umat Kristen.

Terdapat kesan bahwa pandangan tentang absolutisme agama didasarkan oleh kandungan ajaran bahwa pemeluk agama tidak dapat objektif terhadap kebenaran lain. Bagi umat Islam barangkali didasarkan pada ajaran bahwa "agama yang paling benar di sisi Allah adalah Islam".

Pengakuan pluralisme secara sosiologis ini juga dikemukakan oleh Mukti Ali. Beliau secara sosial tidak mempersoalkan adanya pluralisme, dalam pengakuan-pengakutan sosial, tetapi ia sangat tegas dalam hal-hal teologis. Ia menegaskan bahwa keyakinan terhadap hal-hal teologis tidak bisa dipakai hukum kompromistis. Oleh karena itu, dalam satu persoalan (objek) yang sama, masing-masing pemeluk agama memiliki sudut pandang yang berbeda-beda, misalnya pandangan tentang al-Qur'an, Bibel, Nabi Muhammad, Yesus dan Mariam.

Menurutnya, orang Islam melakukan penghargaan yang tinggi terhadap Mariam dan Jesus. Hal itu merupakan bagian keimanan orang Islam. Orang Islam sungguh tidak dapat mempercayai (mengimani) ketuhanan Jesus Kristus tetapi mempercayai kenabiannya sebagaimana Nabi Muhammad. Kemudian, orang Islam juga tidak hanya memandang al-Qur'an tetapi juga Torah dan Injil sebagai Kitab Suci (Kitabullah). Yang menjadi persoalan, apakah Kitab Bibel yang ada sekarang ini otentik atau tidak, dan apakah seluruhnya merupakan wahyu Tuhan. Hal ini bukan berarti bahwa orang Islam selalu menolak Wahyu Tuhan yang diturunkan kepada Nabi Musa, Isa atau rasul-rasul lain, meskipun orang Islam tidak bisa mengakui bahwa Bibel sebagaimana sebelum mereka hari ini terdiri dari Kalam Tuhan seluruhnya. 
Namun demikian, orang Islam percaya bahwa Bibel memuat/mengandung Kalam Tuhan. ${ }^{5}$

Tampak Mukti Ali ingin menegaskan bahwa masing-masing agama memiliki keyakinan teologis yang tidak bisa dikompromikan. Islam memiliki keimanan sendiri, bahkan termasuk mengenai hal-hal yang diyakini oleh umat agama lain, misalnya konsep tentang Nabi Isa. Begitu juga, Kristen memiliki keimanan sendiri, bahkan termasuk mengenai hal-hal yang diyakini oleh Islam, misalnya konsep tentang Nabi Muhammad.

Jadi, pengakuan tentang pluralismenya berada pada tataran sosial, yakni bahwa secara sosiologis kita memiliki keimanan dan keyakinan masing-masing. Persoalan kebenaran adalah persoalan dalam wilayah masing-masing agama.

Mukti Ali menjelaskan bahwa ada beberapa pemikiran diajukan orang untuk mencapai kerukunan dalam kehidupan beragama. Pertama, sinkretisme, yaitu pendapat yang menyatakan bahwa semua agama adalah sama. Kedua, reconception, yaitu menyelami dan meninjau kembali agama sendiri dalam konfrontasi dengan agama-agama lain. Ketiga, sintesis, yaitu menciptakan suatu agama baru yang elemen-elemennya diambilkan dari pelbagai agama, supaya dengan demikian tiap-tiap pemeluk agama merasa bahwa sebagian dari ajaran agamanya telah terambil dalam agama sintesis (campuran) itu. Keempat, penggantian, yaitu mengakui bahwa agamanya sendiri itulah yang benar, sedang agama-agama lain adalah salah; dan berusaha supaya orang-orang yang lain agama masuk dalam agamanya. Kelima, agree in disagreement (setuju dalam perbedaan), yaitu percaya bahwa agama yang dipeluk itulah agama yang paling baik, dan mempersilahkan orang lain untuk mempercayai bahwa agama yang dipeluknya adalah agama yang paling baik. Diyakini bahwa antara satu agama dan agama lainnya, selain terdapat perbedaan, juga terdapat persamaan. ${ }^{6}$

Mukti Ali sendiri setuju dengan jalan "agree in disagreement". Ia mengakui jalan inilah yang penting ditempuh untuk menimbulkan kerukunan hidup beragama. Orang yang beragama harus percaya bahwa agama yang ia

${ }^{5}$ Mukti Ali, "Dialog between Muslims and Christians in Indonesia and its Problems" dalam Al-Jami'ah, No. 4 Th. XI Djuli 1970, hlm. 55.

${ }^{6}$ A. Mukti Ali, "Ilmu Perbandingan Agama, Dialog, Dakwah dan Misi", dalam Burhanuddin Daja dan Herman Leonard Beck (red.), Ilmu Perbandingan agama di Indonesia dan Belanda, (Jakarta : INIS, 1992), hlm. 227-229. 
peluk itulah agama yang paling baik dan paling benar, dan orang lain juga dipersilahkan, bahkan dihargai, untuk percaya dan yakin bahwa agama yang dipeluknya adalah agama yang paling baik dan paling benar. ${ }^{7}$

Wacana pluralisme agama Djohan Effendi berbeda dengan pluralisme Rasjidi dan Mukti Ali di atas. Pengakuan pluralisme Djohan Effendi bukan hanya pengakuan secara sosiologis bahwa umat beragama berbeda, tetapi juga pengakuan tentang titik temu secara teologis di antara umat beragama. Djohan tidak setuju dengan absolutisme agama. Ia membedakan antara agama itu sendiri dengan keberagamaan manusia. Pengertian antara agama dan keberagamaan harus dipahami secara proporsional. Menurutnya, agama terutama yang bersumber pada wahyu, diyakini sebagai bersifat ilahiyah Agama memiliki nilai mutlak. Namun, ketika agama itu dipahami oleh manusia, maka kebenaran agama itu tidak bisa sepenuhnya ditangkap dan dijangkau oleh manusia, karena manusia sendiri bersifat nisbi. Oleh karena itu, kebenaran apapun yang dikemukakan oleh manusia -termasuk kebenaran agama yang dikatakan oleh manusia- bersifat nisbi, tidak absolut. Yang absolut adalah kebenaran agama itu sendiri, sementara kebenaran agama yang dikatakan oleh manusia itu nisbi. Kebenaran absolut itu hanya bisa diketahui oleh ilmu Tuhan. ${ }^{8}$

Dengan bahasa lain, Greg Barton menyebut bahwa Djohan Effendi menolak absolutisme agama dan mengakui pluralisme agama. ${ }^{9}$

Djohan mengemukakan:

"Sebagai makhluk yang bersifat nisbi, pengertian dan pengetahuan manusia tidak mungkin mampu menjangkau dan menangkap agama sebagai doktrin kebenaran secara tepat dan menyeluruh. Hal itu hanya ada dalam ilmu Tuhan. Dengan demikian apabila seorang penganut mengatakan perkataan agama, yang ada dalam pikirannya bukan hanya agama sendiri, akan tetapi juga aliran yang dianutnya, bahkan pengertian dan pemahamannya sendiri. Oleh karena itu, pengertian dan pemahamannya tentang agama jelas bukan agama

${ }^{7}$ Ibid., hlm. 230.

${ }^{8}$ Djohan Effendi, "Dialog Antar Agama: Bisakah Melahirkan Teologi Kerukunan?", dalam Majalah Prisma 5, Juni 1978, hlm. 16. Lihat juga Djohan Effendi, "Kemusliman dan Kemajemukan Agama" dalam Th. Sumarthana dkk. (ed.), Dialog: Kritik dan Identitas Agama, hlm. 54-58.

${ }^{9}$ Lihat Greg Barton, Gagasan Islam Liberal di Indonesia: Pemikiran Neo-Modernisme Nurcholish Madjid, Djohan Effeni, Ahmad Wahib dan Abdurrahman Wahid, pent. Nanang Tahqiq (Jakarta : Paramadina, 1999), cet. I, hlm. 237. 
itu sendiri dan karena itu tidak ada alasan untuk secara mutlak dan a priori menyalahkan pengertian dan pemahaman orang lain." 10

Pemikiran pluralisme Djohan Efendi berangkat dari suatu pemahaman bahwa dakwah (baik Islam maupun Kristen) adalah sesuatu yang penting, tapi ia kurang setuju jika keberagamaan seperti itu bertolak dari pandangan keagamaan yang bersifat mutlak dan statis (menganggap bahwa kebenaran atau keselamatan menjadi klaim satu kelompok). Dari sinilah, menurut Djohan, dialog merupakan sesuatu yang esensial untuk merangsang keberagamaan kita agar tidak mandeg dan statis. ${ }^{11}$ Sekali lagi, Djohan tidak menyetujui absolutisme agama, sehingga paksaan atau kekerasan apapun tidak boleh mendapat tempat di dalam usaha-usaha dakwah. Dalam hal ini, yang dibutuhkan adalah sikap moderat dan liberal terhadap iman lain. Dari situlah, teologi kerukunan akan bisa terwujud. Djohan mengemukakan:

\begin{abstract}
"Dengan pendekatan dan pemahaman yang menyadari sepenuhnya akan keterbatasan dan ketidakmutlakan manusia, boleh jadi bisa dikembangkan semacam Teologi Kerukunan, yaitu suatu pandangan keagamaan yang tidak bersifat memonopoli kebenaran dan keselamatan, suatu pandangan keagamaan yang didasarkan atas kesadaran bahwa agama sebagai ajaran kebenaran tidak pernah tertangkap dan terungkap oleh manusia secara penuh dan utuh, dan bahwa keagamaan seseorang pada umumnya, lebih merupakan produk, atau setidak-tidaknya pengaruh lingkungan."
\end{abstract}

Djohan membuat garis pembatas yang tegas antara agama dan keberagamaan. Kedua hal ini tidak dapat dicampuraduk. Ia tidak setuju terhadap pandangan keagamaan seseorang -sebagai suatu keberagamaan-yang dianggap bersifat absolut. Absolutisme keberagamaan adalah tidak benar. Berbagai persoalan yang menimpa umat beragama sering kali disebabkan adanya pandangan bahwa keberagamaan seseorang sebagai satusatunya yang paling benar, sementara keberagamaan orang lain salah. Inilah

\footnotetext{
${ }^{10}$ Djohan Effendi, "Dialog Antar Agama”, hlm. 16. Paragraf ini juga pernah dikutip oleh Greg Barton. Lihat Greg Barton, Gagasan Islam Liberal, hlm. 239.

${ }^{11 D j o h a n ~ E f f e n d i, ~ “ D i a l o g ~ A n t a r ~ A g a m a ”, ~ h l m . ~} 17$.

${ }^{12}$ Ibid. Paragraf ini juga pernah dikutip oleh Greg Barton. Lihat Greg Barton, Gagasan Islam Liberal, hlm. 243.
} 
yang kemudian menumbuhsuburkan adanya misi, zending, dakwah dan semacamnya.

Menurutnya, Islam secara tegas memberikan kebebasan sepenuhnya kepada manusia dalam masalah agama dan keberagamaan. Ia merujuk ayat al-Qur'an yang menyatakan bahwa "tak ada paksaan dalam agama." 13 Ia juga merujuk ayat yang menunjukkan bahwa Tuhan mempersilahkan siapa saja yang mau beriman atau kufur terhadap-Nya. ${ }^{14}$ Menurutnya, Islam sama sekali tidak menafikan agama-agama yang ada. Islam mengakui eksistensi agama-agama tersebut dan tidak menolak nilai-nilai ajarannya. Kebebasan beragama dan respek terhadap agama dan kepercayaan orang lain adalah ajaran agama, disamping itu memang merupakan sesuatu yang penting bagi masyarakat majemuk. Dengan demikian, membela kebebasan beragama bagi siapa saja dan menghormati agama dan kepercayaan orang lain dianggap sebagai bagian dari kemusliman. ${ }^{15}$ Ia merujuk ayat al-Qur'an yang menyatakan keharusan membela kebebasan beragama yang disimbolkan dengan sikap mempertahankan rumah-rumah ibadah seperti biara, gereja, sinagog, dan masjid. ${ }^{16}$

Hal yang sama juga dikemukan oleh Nurcholis Madjid. Ia mengemukakan ketidaksetujuannya dengan absolutisme, karena absolutisme adalah pangkal dari segala permusuhan. Ia mengatakan:

"Petunjuk konkret lain untuk memelihara ukhuwah adalah tidak dibenarkannya sama sekali suatu kelompok dari kalangan orangorang beriman untuk memandang rendah atau kurang menghargai kelompok lainnya, sebab siapa tahu mereka yang dipandang rendah itu lebih baik daripada mereka yang memandang rendah. Ini mengajajarkan kita -dalam pergaulan dengan sesama manusia, khususnya sesama kalangan yang percaya kepada Tuhan-tidak melakukan absolutisme, suatu pangkal dari segala permusuhan."

Nurcholish menegaskan betapa pentingnya kehidupan beragama. Ia tidak menjelaskan secara tegas apakah yang dimaksud agama di sini adalah

${ }^{13}$ Q.S. Al-Baqarah (2) : 156.

${ }^{14}$ Q.S. Al-Kahfi (18) : 29.

${ }^{15}$ Djohan Effendi, “Kemusliman dan Kemajemukan”, hlm. 54-55.

${ }^{16}$ Q.S. Al-Hajj (22) : 40.

17Paragraf itu merupakan komentar Nurcholish Madjid yang dicantumkan dalam buku Atas Nama Agama. Lihat Andito (ed.), Atas Nama Agama: Wacana Agama dalam Dialog "Bebas" Konflik, (Bandung : Pustaka Hidayah, 1998), hlm. 259. 
agama Islam saja. Artinya, agama yang dimaksud adalah agama secara umum. Namun, dengan bahasa yang dialektis, ia melakukan otokritik terhadap pemeluk agama. Ia mengakui bahwa dalam agama-agama, lebih tepatnya, dalam lingkungan para penganut agama-agama, selalu ada potensi kenegatifan dan perusakan yang amat berbahaya. ${ }^{18}$

Nurcholish melihat bahwa peta tahun 1992 sedang ditandai oleh konflik-konflik dengan warna keagamaan. Diakui, agama memang bukan satu-satunya faktor, ${ }^{19}$ tapi jelas sekali bahwa pertimbangan keagamaan dalam konflik-konflik itu dan dalam eskalasinya sangat banyak memainkan peran. Setiap warna keagamaan dalam suatu konflik seringkali melibatkan agama formal atau agama terorganisir (organized religion). Ia menyebut tempattempat konflik; Irlandia, sekitar Perancis dan Jerman, Bosnia-Herzegovina, Cyprus, Palestina, Timur Dekat, Afrika Hitam, Sudan, Perang Teluk, Pakistan, Srilangka, Burma, Thailang, dan Filipina. ${ }^{20}$

Menanggapi semboyan yang diperkenalkan oleh futurolog, John Naisbitt dan Patricia Aburdene, Spiritualiy, Yes; Organized Religion, No, Nurcholish menyatakan bahwa semboyan itu mengandung makna prinsipil daripada semboyan yang pernah ia kemukakan 20 tahun sebelumnya -"Islam, Yes; Partai Islam, No". Nurcholish mengaku mengalami kesulitan besar, bahkan kemustahilan, untuk dapat menerima kebenarannya. Ia juga menegaskan bahwa semboyan Spirituality, Yes; Organized Religion, No, agaknya tidak memiliki pijakan yang kuat. ${ }^{21}$ Artinya, agama-agama resmi memang masih menjadi fenomena yang banyak memainkan peran dalam kehidupan manusia.

18Tulisan Nurcholish Madjid yang penuh dengan nuansa dialog ini disampaikan di Taman Ismail Marzuki 21 Oktober 1992, Beberapa Renungan tentang Kehidupan Keagamaan untuk Generasi Mendatang. Pengamatan terhadap realitas pluralitas umat menjadi perhatian serius. Sebagaimana judulnya, ia mengupas bagaimana generasi mendatang menjalankan kehidupan beragama. Kata generasi mendatang adalah kata yang masih umum yang tidak perlu dikotak hanya dalam generasi Islam. Dalam tulisannya itu, Nurcholish ingin melaksanakan kandungan hadis yang menyatakan "agama adalah pesan" (al-dîn al-nashîhah). Lihat Nurcholish Madjid, "Beberapa Renungan tentang Kehidupan Keagamaan untuk Generasi Mendatang", dalam Jurnal Ulumul Qur'an, No.1 Vol.IV, Th. 1993, hlm. 4 dan 6.

${ }^{19}$ Faktor-faktor selain agama, misalnya, adalah faktor kebangsaan, kesukuan, kebahasaan, kesenjangan ekonomi, kesejarahan, kekuasaan teritorial, dan sebagainya.

${ }^{20}$ Nurcholish Madjid, “Beberapa Renungan”, hlm. 7-8.

${ }^{21} \mathrm{Ibid} ., \mathrm{hlm} .8$. 
Merujuk pada Kitab Suci al-Qur'an, Nurcholish menegaskan bahwa setiap umat atau golongan manusia telah pernah dibangkitkan atau diutus seorang utusan Tuhan, dengan tugas menyeru umatnya untuk menyembah kepada Tuhan saja (dalam pengertian paham Ketuhanan Yang Maha Esa yang murni). Ia mengutip Surat al-Nahl (16): 36. Berdasarkan firman-firman Allah itu dikatakan bahwa:

“... semua agama Nabi dan Rasul yang telah dibangkitkan dalam setiap umat adalah sama, dan inti dari ajaran semua Nabi dan Rasul itu ialah Ketuhanan Yang Maha Esa dan perlawanan terhadap kekuatan-kekuatan tiranik. Dengan perkataan lain, Ketuhanan Yang Maha Esa dan perlawanan terhadap tirani adalah titik pertemuan, common platform atau, dalam bahasa al-Qur'an, kalimatun-sawâ', (kalimat atau ajaran yang sama) antara semua kitab suci.",22

Menurut Nurcholish, kesamaan-kesamaan yang ada dalam agamaagama bukanlah sesuatu yang mengejutkan. Ia berargumentasi, semua yang benar berasal dari sumber yang sama, yaitu Allah, Yang Maha Benar (alHaqq). Semua Nabi dan Rasul membawa ajaran kebenaran yang sama. Sementara itu, adanya perbedaan itu hanyalah dalam bentuk-bentuk responsi khusus tugas seorang Rasul kepada tuntutan zaman dan tempatnya. Ditegaskan bahwa perbedaan itu tidaklah prinsipil, sedangkan ajaran pokok atau syariat para Nabi dan Rasul adalah sama. Dalam rangka menjelaskan hal ini, ia mengutip al-Qur'an, yakni dalam Surat Al-Syûrâ (42):13, al-Nisâ' (4):163-165, al-Baqarah (2):136, al-Ankabût (29):46, Al-Syûrâ (42):15, dan al-Mâidah (5):8. Ayat-ayat yang dikutip itu berkenaan dengan kesamaan antara syariat Muhammad dengan syariat Nuh, Ibrahim, Isma'il, Ishaq, Ya'qub, Ayyub, Yunus, Harun, Musa, Sulaiman, Dawud, Isa dan kepada rasul-rasul yang tidak dikisahkan kepada Muhammad. ${ }^{23}$ Ayat-ayat itu menunjukkan adanya kesinambungan, kesatuan dan persamaan agama-agama para Nabi dan Rasul Allah. Nurcholish mengritik masyarakat sekarang ini, baik Muslim maupun yang bukan, karena banyak yang tidak menyadari adanya pandangan itu.

Menjelasakan tentang titik temu agama-agama, ada empat prinsip yang dikemukakan oleh Nurcholish. Pertama, Islam mengajarkan bahwa agama Tuhan adalah universal, karena Tuhan telah mengutus Rasul-Nya kepada

${ }^{22}$ Ibid., hlm. 12.

${ }^{23}$ Ibid., hlm. 13-14. 
setiap umat manusia. Kedua, Islam mengajarkan pandangan tentang kesatuan nubuwwah (kenabian) dan umat yang percaya kepada Tuhan. Ketiga, agama yang dibawa Nabi Muhammad adalah kelanjutan langsung agama-agama sebelumnya, khususnya yang secara "genealogis" paling dekat ialah agamaagama Semitik-Abrahamik. Keempat, umat Islam diperintahkan untuk menjaga hubungan yang baik dengan orang-orang beragama lain, khususnya para penganut kitab suci (Ahl al-Kitab) ${ }^{24}$ Semua prinsip itu mengarah pada ajaran "tidak boleh ada paksaan dalam agama".

Menurut Nurcholish, pandangan-pandangan inklusivitas amat relevan untuk dikembangkan pada zaman sekarang, yaitu zaman globalisasi berkat teknologi informasi dan transportasi, yang membuat umat manusia hidup dalam sebuah "desa buwana" (global village). Ia menegaskan:

"Dalam desa buwana itu, seperti telah disinggung, manusia akan semakin intim dan mendalam mengenal satu sama lain, tetapi sekaligus juga lebih mudah terbawa kepada penghadapan dan konfrontasi langsung. Karena itu sangat diperlukan sikap-sikap saling mengerti dan paham, dengan kemungkinan mencari dan menemukan titik kesamaan atau kalimatun sawa' seperti diperintahkan Allah dalam al-Qur'an. Dengan tegas al-Qur'an melarang pemaksaan suatu agama kepada orang atau komunitas lain, betapapun benarnya agama itu, karena akhirnya hanya Allah yang bakal mampu memberi petunjuk kepada seseorang, secara pribadi. Namun, demi kebahagiaannya sendiri, manusia harus terbuka kepada setiap ajaran atau pandangan, kemudian bersedia mengikuti mana yang terbaik. Itulah pertanda adanya hidayah Allah kepada mereka. Dan patut kita camkan benar-benar pendapat Sayyid Muhammad Rasyid Ridla sebagaimana dikutip oleh 'Abdul Hamid Hakim bahwa pengertian sebagai Ahl al-kitab tidak terbatas hanya kepada kaum Yahudi dan Kristen seperti tersebut dengan jelas dalam al-Qur'an serta kaum Majusi (pengikut Zoroaster) seperti tersebut dalam sebuah hadits, tetapi juga mencakup agama-agama lain yang mempunyai suatu bentuk kitab suci." 25

Nurcholish menyinggung tentang bagaimana sikap keberagamaan yang benar. Ia menegaskan bahwa sebaik-baik agama di sisi Allah ialah al-

${ }^{24}$ Lihat Nurcholish Madjid, "Hubungan Antar Umat Beragama : Antara Ajaran dan Kenyataan", dalam W.A.L. Stokhof (red.), Ilmu Perbandingan Agama di Indonesia (Beberapa Permasalahan), ( Jakarta : INIS, 1990), jilid VII, hlm. 108-109.

${ }^{25}$ Nurcholish Madjid, "Beberapa Renungan”, hlm. 16. 
hanîfiyyah al-samhah, agama yang memiliki semangat kebenaran yang lapang dan terbuka. Ia mengemukakan:

"Sikap mencari Kebenaran secara tulus dan murni (hanîfiyyah, kehanifan) adalah sikap keagamaan yang benar, yang menjanjikan kebahagiaan sejati, dan yang tidak bersifat palliative atau menghibur secara semu dan palsu seperti halnya kultus dan fundamentalisme. Maka Nabi pun menegaskan bahwa sebaik-baik agama di sisi Allah ialah al-hanîfiyyah al-samhah (baca: "al-hanîfiyyatus-samhah") yaitu semangat mencari kebenaran yang lapang, toleran, tidak sempit, tanpa kefanatikan, dan tidak membelenggu jiwa." 26

Oleh karena itu, umat Islam tidak dilarang untuk berbuat baik dan adil kepada siapapun dari kalangan bukan Muslim yang tidak menunjukkan permusuhan, baik atas nama agama atau lainnya, seperti penjajahan, pengusiran dari tempat tinggal dan bentuk penindasan yang lain. ${ }^{27}$

Sementara itu, Abdurrahman Wahid menegaskan masalah pluralisme bukan dalam pengertian pluralisme yang dikemukakan oleh Djohan Effendi dan Nurcholish Madjid di muka. Ia menekankan pandangan keterbukaan untuk menemukan kebenaran di mana pun juga. ${ }^{28}$ Pluralisme yang ditekankan Gus Dur adalah pluralisme dalam bertindak dan berpikir. Inilah yang melahirkan toleransi. Sikap toleran tidak bergantung pada tingginya tingkat pendidikan formal atau pun kepintaran pemikiran secara alamiah, tetapi merupakan persoalan hati, persoalan perilaku. Tidak pula harus kaya dulu. Bahkan, seringkali semangat ini terdapat justru pada mereka yang tidak pintar juga tidak kaya, yang biasanya disebut "orang-orang terbaik'. ${ }^{29}$ Gus Dur memberi contoh sebagaimana yang dilakukan oleh Kyai Iskandar, dengan cara bergaul secara berbaur dalam masyarakat.

Gus Dur mengembangkan pandangan anti eksklusivisme agama. Menurutnya, berbagai peristiwa kerusuhan yang berkedok agama di beberapa

26Ibid., hlm. 19.

${ }^{27}$ Q.S. Al-Mumtahanah (60) : 8. Lihat Nurcholish Madjid, "Hubungan Antar Umat Beragama", hlm. 111.

${ }^{28}$ Abdurrahman Wahid, Muslim di Tengah Pergumulan, (Jakarta : Lappenas, 1981), hlm. 3.

${ }^{29}$ Lihat Greg Barton, Gagasan Islam Liberal, hlm. 398. 
tempat adalah akibat adanya eksklusivisme agama. ${ }^{30}$ Apa yang disampaikan oleh Gus Dur sebenarnya lebih merupakan otokritik bagi umat Islam sendiri, karena adanya politisasi agama dan pendangkalan agama.

Berkenaan dengan makna salah satu ayat al-Qur'an Surat Al-Fath (48) ayat 9 yang berbunyi "Asyiddâ-u âlâ al-Kuffârm ruhamâ-u bayna hum, ia memahami bahwa ada perbedaan antara orang non-Muslim sekarang dengan kaum kafir yang memerangi agama Islam (dalam konteks ayat itu adalah kaum kafir Mekkah). Oleh karena itu, tidak ada alasan untuk mengembangkan sikap permusuhan kepada mereka selama tidak memerangi agama Islam. Selain itu, menurutnya, esensi "saling menyantuni" justru terletak pada sikap-sikap di mana kita bisa saling mengoreksi sesama orang Islam. Nabi pernah mencontohkan, bahwa jika Fatimah (putri beliau) melakukan pencurian maka ia tetap harus dihukum. Jadi, sikap santun tidak boleh dengan standar ganda atau tidak boleh mengabaikan keadilan kepada siapa pun, termasuk orang berlainan agama. ${ }^{31}$

Kemudian, berkenaan dengan bunyi ayat al-Qur'an dalam Surat AlBaqarah (2) ayat 120 (Wahai Muhammad, sesungguhnya orang-orang Yahudi dan Nasrani tidak akan rela kepadamu sampai kamu ikuti agama mereka, Gus Dur memandang bahwa ayat ini sering digunakan untuk membenarkan sikap dan tindakan anti-toleransi, karena kata "tidak rela" di sini dianggap melawan atau memusuhi, lalu dikaitkan dengan pembuatan gereja-gereja, penginjilan atau pekabaran Injil, dan sebagainya. Menurutnya, kata "tidak rela" harus didudukkan secara proporsional. Tidak rela itu artinya tidak bisa menerima konsep-konsep dasar. Tentu saja, ini tidak bisa dipungkiri oleh siapapun. Tidak menerima konsep dasar bukan berarti mesti mengembangkan sikap permusuhan atau perlawanan. Kristen dan Yahudi tidak bisa menerima konsep dasar Islam adalah sudah pasti. Begitu juga sebaliknya, Islam juga tidak bisa menerima konsep dasar agama Kristen dan Yahudi. Oleh karena itu, menurutnya, kita tidak akan goyang dari konsep Tauhid, tapi kita menghargai pendapat orang lain. ${ }^{32}$ Pendapat orang lain ini tentu saja berarti keyakinan orang lain.

\footnotetext{
${ }^{30}$ Abdurrahman Wahid, "Dialog Agama dan Masalah Pendangkalan Agama", dalam Komaruddin Hidayat dan Ahmad Gaus AF (ed.), Passing Over: Melintasi Batas Agama (Jakarta : Gramedia Pustaka Utama, 1998), hlm. 52.

31 Ibid., hlm. 53.

${ }^{32}$ Ibid., hlm. 53-54.
} 
Sementara itu, Alwi Shihab menunjukkan dua komitmen penting yang harus dipegang oleh dialog, yaitu sikap toleransi dan sikap pluralisme. Toleransi adalah upaya untuk menahan diri agar potensi konflik dapat ditekan. Adapun yang dimaksud dengan pluralisme adalah (1) tidak semata menunjuk pada kenyataan tentang adanya kemajemukan, namun adanya keterlibatan aktif terhadap kenyataan kemajemukan tersebut. Pengertian pluralisme agama adalah bahwa tiap pemeluk agama dituntut bukan saja mengakui keberadaan dan hak agama lain, tapi terlibat dalam usaha memahami perbedaan dan persamaan guna tercapainya kerukunan, dalam kebhinekaan. (2) pluralisme harus dibedakan dengan kosmopolitanisme. Kosmopolitanisme menunjuk pada suatu realita di mana aneka ragam agama, ras, bangsa hidup berdampingan di suatu lokasi. Namun, interaksi positif antar penduduk ini, khususnya di bidang agama, sangat minimal, kalaupun ada. (3) konsep pluralisme tidak dapat disamakan dengan relativisme. Karena, konsekuensi dari paham relativisme agama bahwa doktrin agama apapun harus dinyatakan benar. Atau, "semua agama adalah sama". Oleh karena itu, seorang relativis tidak akan mengenal, apalagi menerima, suatu kebenaran universal yang berlaku untuk semua dan sepanjang masa. Namun demikian, paham pluralisme terdapat unsur relativisme, yakni unsur tidak mengklaim kebenaran tunggal (monopoli) atas suatu kebenaran, apalagi memaksakan kebenaran tersebut kepada pihak lain. Paling tidak, seorang pluralis akan menghindari sikap absolutisme yang menonjolkan keunggulannya terhadap pihak lain. (4) pluralisme agama bukanlah sinkretisme, yakni menciptakan suatu agama baru dengan memadukan unsur tertentu atau sebagian komponen ajaran dari beberapa agama untuk dijadikan bagian integral dari agama baru tersebut. ${ }^{33}$

Satu hal yang ditegaskan oleh Alwi adalah apabila konsep pluralisme agama hendak diterapkan di Indonesia, maka ia harus bersyaratkan komitmen yang kokoh terhadap agama masing-masing. Seorang pluralis, dalam berinteraksi dengan aneka ragam agama, tidak saja dituntut untuk membuka diri, belajar dan menghormati mitra dialognya, tetapi yang terpenting ia harus committed terhadap agama yang dianutnya. Hal ini untuk menghindari relativisme agama. Ia menekankan perlunya membudayakan sikap

${ }^{33}$ Alwi Shihab, Islam Inklusif: Menuju Sikap Terbuka dalam Beragama (Bandung : Mizan, 1999), cet. VII, hlm. 41-43. 
keterbukaan, menerima perbedaan, dan menghormati kemajemukan agama, dibarengi loyalitas komitmen terhadap agama masing-masing. ${ }^{34}$

Alwi menegaskan, Islam sejak semula menganjurkan dialog dengan umat lain. Dikatakan, terhadap pengikut Isa a.s. dan Musa a.s., al-Qur'an menggunakan kata ahl al-kitab (yang memiliki kitab suci). Penggunaan kata $a h l$, yang berarti keluarga, menunjukkan keakraban dan kedekatan hubungan. ${ }^{35}$

Dari berbagai pandangan tentang pluralisme di atas Penulis dapat mengklasifikasi ada tiga model pluralisme. Pertama, pandangan pluralisme yang masih menyisakan adanya absolutisme agama. Pandangan ini dikemukakan Rasjidi dan Natsir. Kedua, pandangan pluralisme liberal. Ini dikemukakan oleh Djohan Effendi, Nurcholish Madjid, dan Abdurrahman Wahid. Ketiga, pandangan pluralisme yang menempati posisi antara absolutisme agama dan pluralisme liberal. Pandangan ini masih memegang adanya hal-hal yang bersifat absolut yang tidak dapat dipertemukan atau disamakan, tetapi juga mengakui bahwa pluralisme itu tidak hanya sekedar ada namun juga harus diwujudkan dalam keterlibatan aktif dalam memahami perbedaan dan persamaan. Ada sikap terbuka, menerima perbedaan, dan menghormati kemajemukan agama, tetapi ada loyalitas komitmen terhadap agama masing-masing. Konsep yang dikemukaan Mukti Ali "agree in disagreement" kiranya dapat mewakili pandangan yang terakhir ini.

Sekarang ini umat beragama dihadapkan pada tantangan munculnya benturan-benturan atau konflik di antara mereka. Yang paling aktual adalah konflik antar umat beragama di Poso. Potensi pecahnya konflik sangatlah besar, sebesar pemilahan-pemilahan umat manusia ke dalam batas-batas objektif dan subjektif peradaban. Menurut Samuel P. Huntington, unsurunsur pembatas objektif adalah bahasa, sejarah, agama, adat istiadat, dan lembaga-lembaga. Unsur pembatas subjektifnya adalah identifikasi dari manusia. Perbedaan antar pembatas itu adalah nyata dan penting. ${ }^{36}$ Secara tidak sadar, manusia terkelompok ke dalam identitas-identitas yang membedakan antara satu dengan lainnya.

${ }^{34}$ Ibid., hlm. 43.

${ }^{35}$ Ibid., hlm. 67.

36Samuel P. Huntington, "Benturan Antar Peradaban, Masa Depan Politik Dunia?" dalam Jurnal Ulumul Qur'an, No. 5, Vol.IV Tahun 1993, hlm. 12. 
Dari klasifikasi di atas, agama merupakan salah satu pembatas peradaban. Artinya, umat manusia terkelompok dalam agama Islam, Kristen, Katolik, Kong Hucu dan sebagainya. Potensi konflik antar mereka tidak bisa dihindari. Oleh karena itu, untuk mengantisipasi pecahnya konflik antar umat beragama perlu dikembangkan upaya-upaya dialog untuk mengeliminir perbedaan-perbedaan pembatas di atas.

Dialog adalah upaya untuk menjembatani bagaimana benturan bisa dieliminir. Dialog memang bukan tanpa persoalan, misalnya berkenaan dengan standar apa yang harus digunakan untuk mencakup beragam peradaban yang ada di dunia. Menurut hemat penulis, perlu adanya standar yang bisa diterima semua pihak. Dengan kata lain, perlu ada standar universal untuk semua. Standar itu hendaknya bermuara pada moralitas internasional atau etika global, yaitu hak asasi manusia, kebebasan, demokrasi, keadilan dan perdamaian. Hal-hal ini bersifat universal dan melampaui kepentingan umat tertentu. ${ }^{37}$

Standar universal ini memang bukan persoalan mudah, karena ia adalah gagasan teoritis yang mungkin berbeda dengan kenyataan-kenyataan di lapangan. Namun, sebagai nilai-nilai universal yang bisa melindungi hak-hak semua masyarakat dunia tampaknya nilai-nilai itu bisa mewakili kebutuhan bersama manusia, paling tidak dari stadar kemanusiaan (manusiawi).

Di sinilah kemudian diperlukan suatu pendekatan dan metodologi yang proporsional baik secara intra-agama maupun antar agama untuk menghindari lahirnya truth claim yang mungkin justru akan memperuncing benturan. Tawaran-tawaran yang telah dikemukakan oleh para cendekiawan muslim Indonesia merupakan sumbangan pemikiran yang dapat menjadi moralitas yang bersifat universal atau menjadi global etik yang dapat dipakai oleh semua orang. Apa yang dikemukakan oleh Rasjidi dengan pluralisme agama secara sosiologis, toleransi agama dan hak asasi manusia, Natsir dengan konsep modus vivendi dan persaudaraan universal yang penuh dengan nuansa hak-hak asasi manusia dan kebebasan beragama, Mukti Ali

${ }^{37}$ Lihat Bassam Tibi, “Moralitas Internasional sebagai Landasan Lintas Budaya", dalam M. Nasir Tamara dan Elza Pelda Taher (ed.), Agama dan Dialog Antar Peradaban (Jakarta : Yayasan Paramadina, 1996), hlm. 163. Lihat juga Parliament of the World's Religions, Declaration Toward a Global Ethic (Chicago : t.t.), hlm. 5. Lihat juga Zainul Abas, "Dialog Agama, Pluralitas Budaya dan Visi Perdamaian”, dalam Kompas, No. 213 Tahun Ke-32, 31 Januari 1997. 
dengan agree in disagreement, Djohan Effendi dengan dimensi moral dan etisnya, Abdurrahman Wahid dengan self-kritiknya dan pluralisme dalam bertindak dan berpikir, Nurcholish Madjid dengan samhah al-hanifiyyah-nya, dan Alwi Shihab dengan sikap toleransi dan sikap pluralisme serta perlunya memahami pesan Tuhan, merupakan upaya untuk mencari solusi bagaimana umat beragama bisa hidup damai dan harmonis.

Selanjutnya, suatu dialog akan dapat mencapai hasil yang diharapkan apabila, paling tidak, memenuhi hal-hal berikut ini. Pertama, adanya keterbukaan atau transparansi. Terbuka berarti mau mendengarkan semua pihak secara proporsional, adil dan setara. Dialog bukanlah tempat untuk memenangkan suatu urusan atau perkara, juga bukan tempat untuk menyelundupkan berbagai "agenda yang tersembunyi" yang tidak diketahui dengan partner dialog. ${ }^{38}$

Kedua adalah menyadari adanya perbedaan. Perbedaan adalah sesuatu yang wajar dan memang merupakan suatu realitas yang tidak dapat dihindari. Artinya, tidak ada yang berhak menghakimi atas suatu kebenaran atau tidak ada "truth claim" dari salah satu pihak. Masing-masing pihak diperlakukan secara sama dan setara dalam memperbincangkan tentang kebenaran agamanya. $^{39}$

Ketiga adalah sikap kritis, yakni kritis terhadap sikap eksklusif dan segala kecenderungan untuk meremehkan dan mendiskreditkan orang lain. Dengan kata lain, dialog ibarat pedang bermata dua; sisi pertama mengarah pada diri sendiri atau otokritik, dan sisi kedua mengarah pada suatu percakapan kritis yang sifatnya eksternal, yaitu untuk saling memberikan pertimbangan serta memberikan pendapat kepada orang lain berdasarkan keyakinannya sendiri. Agama bisa berfungsi sebagai kritik, artinya kritik pada pemahaman dan perilaku umat beragama sendiri. ${ }^{40}$

${ }^{38}$ Ibid.

${ }^{39}$ Lihat Tarmizi Thaher, "Kerukunan Hidup Umat Beragama dan Studi AgamaAgama di Indonesia" dalam Mursyid Ali (ed.), Studi Agama-Agama di Perguruan Tinggi, Bingkai Sosio-Kultural Kerukunan Hidup Antar Umat Beragama di Indonesia, (Jakarta : Balitbang Depag RI, 1998/1999), hlm. 2-3. Lihat juga Komaruddin Hidayat, "Lingkup dan Metodologi Studi Agama-Agama" dalam Mursyid Ali (ed.), Studi Agama-Agama, hlm. 35-36.

${ }^{40}$ Lihat Komaruddin Hidayat, "Lingkup dan Metodologi Studi AgamaAgama", hlm. 42. 
Keempat adalah adanya persamaan. Suatu dialog tidak dapat berlangsung dengan sukses apabila satu pihak menjadi "tuan rumah" sedangkan lainnya menjadi "tamu yang diundang". Tiap-tiap pihak hendaknya merasa menjadi tuan rumah. Tiap-tiap pihak hendaknya bebas berbicara dari hatinya., sekaligus membebaskan dari beban: misalnya kewajiban terhadap pihak lainnya, maupun kesediaannya pada organisasinya dan pemerintahannya. Suatu dialog hendaknya tidak ada "tangan di atas' dan "tangan di bawah", semuanya harus sama. ${ }^{41}$

Kelima, adalah ada kemauan untuk memahami kepercayaan, ritus, dan simbol agama dalam rangka untuk memahami orang lain secara benar. Masing-masing pihak harus mau berusaha melakukan itu agar pemahaman terhadap orang lain tidak hanya di permukaan saja tetapi bisa sampai pada bagiannya yang paling dalam (batin). Dari situlah bisa ditemukan dasar yang sama sehingga dapat menjadi landasan untuk hidup bersama di dunia ini secara damai, meskipun adanya perbedaan juga menjadi kenyataan yang tidak dapat dipungkiri. ${ }^{42}$

Namun demikian, penulis melihat adanya berbagai permasalahan yang dapat menjadi penghambat dialog antar umat beragama. Di antara sesuatu yang dapat menjadi penghambat itu adalah sebagai berikut: (1) kurang memiliki pengetahuan dan pemahaman tentang agama-agama lain secara benar dan seimbang, akibatnya kurang penghargaan dan muncul sikap saling curiga yang berlainan. Hal ini akibat adanya truth claim, atau sesuatu yang akan mengakibatkan adanya truth claim. ${ }^{43}$ (2) Faktor-faktor sosial politik dan trauma akan konflik-konflik dalam sejarah, misalnya Perang Salib atau konflik antar agama yang pernah terjadi di suatu daerah tertentu. (3) Munculnya sekte-sekte keagamaan yang tidak ada sikap kompromistik dengan memakai ukuran kebenaran hitam-putih. (4) Kesenjangan sosial ekonomi, terkurung dalam ras, etnis dan golongan tertentu. ${ }^{44}$ (5) Masih

\footnotetext{
${ }^{41}$ Ismail Raji al-Faruqi (ed.), Trialog Tiga Agama Besar: Yahudi, Kristen, Islam, alih bahasa Joko Susilo Kahhar dan Supriyanto Abdullah, Cet. I (Surabaya : Pustaka Progressif, 1994), hlm. 12.

${ }^{42}$ Lihat St. Sunardi, "Dialog:Cara Baru Beragama”, hlm. 76.

$43 \mathrm{Hal}$ ini adalah antitesis dari prasyarat dialog yang mengharuskan adanya saling pemahaman terhadap berbagai macam agama. Jika masing-masing tidak memahami secara benar terhadap agama orang lain maka ini akan menjadi penghambat dialog, karena akan muncul kecurigaan-kecurigaan.

${ }^{44}$ Poin 3 dan 4 lihat A. Ligoy, CP, “Gereja Indonesia”, hlm. 131.
} 
adanya kecurigaan dan ketidakpercayaan kepada orang lain. Atau dengan kata lain, kerukunan yang ada hanyalah kerukunan semu. (8) Penafsiran tentang misi atau dakwah yang konfrontatif. (9) Ketegangan politik yang melibatkan kelompok agama. ${ }^{45}$

\section{Kesimpulan}

Dari beberapa uraian diatas dapat disimpulkan beberapa kesimpulan sebagai berikut: Pertama, adanya keterbukaan atau transparansi. Kedua adalah menyadari adanya perbedaan. Perbedaan adalah sesuatu yang wajar dan memang merupakan suatu realitas yang tidak dapat dihindari. Ketiga adalah sikap kritis, yakni kritis terhadap sikap eksklusif dan segala kecenderungan untuk meremehkan dan mendiskreditkan orang lain. Keempat adalah adanya persamaan. Suatu dialog tidak dapat berlangsung dengan sukses apabila satu pihak menjadi "tuan rumah" sedangkan lainnya menjadi "tamu yang diundang".

Dan yang terakhir (kelima) adalah ada kemauan untuk memahami kepercayaan, ritus, dan simbol agama dalam rangka untuk memahami orang lain secara benar. Masing-masing pihak harus mau berusaha melakukan itu agar pemahaman terhadap orang lain tidak hanya di permukaan saja tetapi bisa sampai pada bagiannya yang paling dalam (batin). Dari situlah bisa ditemukan dasar yang sama sehingga dapat menjadi landasan untuk hidup bersama di dunia ini secara damai, meskipun adanya perbedaan juga menjadi kenyataan yang tidak dapat dipungkiri.

${ }^{45}$ Umar Hasyim, Toleransi dan Kemerdekaan Beragama dalam Islam sebagai Dasar Menuju Dialog dan Kerukunan Antar Agama (Surabaya : PT. Bina Ilmu, t.t.), hlm. 350351. 


\section{DAFTAR PUSTAKA}

Wahid, Abdurrahman. Muslim di Tengah Pergumulan, (Jakarta : Lappenas, 1981).

Shihab, Alwi. Islam Inklusif: Menuju Sikap Terbuka dalam Beragama (Bandung : Mizan, 1999), cet. VII.

Abdullah, M. Amin, "Etika dan Dialog Antar Agama: Perspektif Islam", dalam Jurnal Ulumul Qur'an. No. 4 Vol. IV. Th. 1993.

Andito (ed.), Atas Nama Agama: Wacana Agama dalam Dialog "Bebas" Konflik, (Bandung : Pustaka Hidayah, 1998), hlm. 259.

Yatim, Badri. Sejarah Peradaban Islam (Jakarta : RajaGrafindo Persada, 1993).

Burhanuddin Daja dan Herman Leonard Beck (red.), Ilmu Perbandingan agama di Indonesia dan Belanda, (Jakarta : INIS, 1992).

Nasution, Chadijah. Sejarah dan Perkembangan Dakwah Islam (Yogyakarta : Ideal Offset, 1978).

Barton, Greg. Gagasan Islam Liberal di Indonesia: Pemikiran NeoModernisme Nurcholish Madjid, Djohan Effeni, Ahmad Wahib dan Abdurrahman Wahid, pent. Nanang Tahqiq (Jakarta : Paramadina, 1999), cet. I.

Guillaume, A., The Life of Muhammad: A Translation of Ibn Ishaq's Sirat Rasul Allah, (Karachi : Oxford University Press, 1970).

Hassan, Hasan Ibrahim Sejarah dan Kebudayaan Islam, terj. Djah dan Humam (Yogyakarta : Kota Kembang, 1989).

Huntington, Samuel P., "Benturan Antar Peradaban, Masa Depan Politik Dunia?" dalam Jurnal Ulumul Qur'an, No. 5, Vol.IV Tahun 1993.

al-Faruqi, Ismail Raji (ed.), Trialog Tiga Agama Besar: Yahudi, Kristen, Islam, alih bahasa Joko Susilo Kahhar dan Supriyanto Abdullah, Cet. I (Surabaya : Pustaka Progressif, 1994). 
Hidayat, Komaruddin dan Ahmad Gaus AF (ed.), Passing Over: Melintasi Batas Agama (Jakarta : Gramedia Pustaka Utama, 1998).

Michael H. Hart, Seratus Tokoh Yang Paling Berpengaruh dalam Sejarah, terj. Mahbub Djunaedi (Jakarta : Pustaka Jaya, 1990), cet. XII.

Watt, Montgomery W., Muhammad at Medina (London : Oxford University Press, 1956).

Haekal, Muhammad Husain Sejarah Hidup Muhammad, terj. Ali Audah (Jakarta : Tintamas, 1984).

Ali, A. Mukti, "Dialog between Muslims and Christians in Indonesia and its Problems" dalam Al-Jami'ah, No. 4 Th. XI Djuli 1970.

Ali, Mursyid (ed.), Studi Agama-Agama di Perguruan Tinggi, Bingkai SosioKultural Kerukunan Hidup Antar Umat Beragama di Indonesia, (Jakarta : Balitbang Depag RI, 1998/1999).

Tamara, M. Nasir dan Elza Pelda Taher (ed.), Agama dan Dialog Antar Peradaban (Jakarta : Yayasan Paramadina, 1996).

Shiddiqi, Nourouzzaman, Jeram-jeram Peradaban Muslim (Yogyakarta : Pustaka Pelajar, 1996).

Madjid, Nurcholish, "Beberapa Renungan tentang Kehidupan Keagamaan untuk Generasi Mendatang", dalam Jurnal Ulumul Qur'an, No.1 Vol.IV, Th. 1993.

Parliament of the World's Religions, Declaration Toward a Global Ethic (Chicago : t.t.).

Sjalabi, A., Sedjarah dan Kebudajaan Islam (Djakarta : Djajamurni, 1970).

Stokhof, W.A.L. (red.), Ilmu Perbandingan Agama di Indonesia (Beberapa Permasalahan), ( Jakarta : INIS, 1990), jilid VII.

Sumarthana, Th. dkk. (ed.), Dialog: Kritik dan Identitas Agama.

Umar Hasyim, Toleransi dan Kemerdekaan Beragama dalam Islam sebagai Dasar Menuju Dialog dan Kerukunan Antar Agama (Surabaya : PT. Bina Ilmu, t.t.). 